\title{
History of Forest in Oudh Region
}

\author{
Richa Tripathi \\ (Research Scholar, History Department, Babasaheb Bhimrao Ambedkar Central University, Lucknow, Uttar \\ Pradesh, India)
}

\begin{abstract}
Environmental history is a very fascinating subject of these days. This subject attracts the environmental historian because modern man is facing plenty of environmental problems. Contemporary society in their search for pleasure and prosperity has exploited nature without any moral restraint to such an extent that nature has been rendered almost incapable of sustaining healthy life. Precious gifts of nature, such as air and water, have been polluted with severely disastrous consequences. Although a more affluent and better educated population showed its concern and demanded a cleaner and healthier environment. There is no doubt that man's intervention with nature was successful in leading to social changes. Oudh is a region where agriculture was a main source of revenue. For this purpose the clearing of forest for the cultivation was generally encouraged by the state. Forest, being based on the yield capacity of the land, competes with a variety of other industries similarly situated. In early $19^{\text {th }}$ century, a rapid deforestation took place under the demographic pressure and demand of wood for the railways. The company government beside encouraging expansion of cultivations also set up general policy of forest reservation and protection mainly to assure timber supply. This paper traces the history of forest in Oudh region.
\end{abstract}

Keywords: Agriculture, Ecology, Environmental Historian, Forestry

\section{Introduction}

The point which interests the historian specially is that of relationship between forests, agriculture and grasslands. Agriculture and grasslands produces food for man and animals, whereas forests produce chiefly cellulose and accessory produce. Foodstuffs cannot be produce in profitable quantity and for any length of time without manuring and intense working of the soil so as to produce and maintain those physical and chemical conditions which are essential for obtaining full crop. Field crop must be cultivated in rotation, because different crops make difference demand on the more important nourishing substances in the soil. Forests are engaged in recreation of society, culture, industries, economy and history of any country and preserve its ecological balance. Agriculture and animal husbandry are dependent on forests and forestlands. It is very well known Hindi proverb "Vano ke hai teen kam upkar mitti, pani aur bayar" marvelously brings forth the varied utility of forests. Forests preserve and improve the moisture regime and supply fresh air and also produce humus that maintains soil fertility. They also influence the local distribution of rainfall by lowering the temperature of moisture-laden winds. Natural forests were composed of a variety of species, producing a highly absorbent soil. It was always considered advisable to have mixed crop of trees for better moisture, conservation of soil and good production. Forests allow rain to percolate into the soil, feeding deep seated perennial springs. This penetration of rain-water is due to the fact that forest soil, mainly owing to the action of tree roots, which ramify through it, is far more porous than soil of identical origin in the open. A layer of spongy humus or a mass of needless and undecomposed vegetable matter can also lead to the absorption of water, prevent the drainage of rainwater and increase the porosity of the soil. The debris of burnt forest waste was a particularly good medium for seed growth and high yields. Abundant supply of such waste was well-suited for agriculture. As a rule, an area was cultivated for only two or three years, after which the soil became exhausted and had to be left fallow for recuperation. This characteristic usually noticed in the Oudh forest tracts and wastelands. The main objective of this paper is to document important political events, geographysical conditions and distribution of forest cover. It also includes brief description of important species of forest trees in Oudh region. Further it will focus on the socio-economic structure of Oudh. Also focus on forest dependent communities and attempt has been made to analyse the importance of forest in the livelihoods of rural communities.

\section{Political history}

Mir Muhammad Amin, a resident of Nishapur in Khurasan migrated to India in $1120 \mathrm{H}$ (1708-09). He was a man of no mean merits, by the dint of which he gradually got himself ennobled as Saadat Khan Burhanul-Mulk Bahadur Bahadur Jang and became the Subahdar (Govenor) of Oudh on $9^{\text {th }}$ September, 1722 it proved to be a momentous appointment so much so that the Province of Oudh became a hereditary possession in the family of Saadat Khan from that date till it was annexed by the Britishers in 1856. It is thus clear that the 
appointment of Saadat Khan to the Province of Oudh man's the genesis of the Kingdom of Oudh. The following Nawabs and Kings adorned the Musnud/ throne of Oudh during the period 1722-1856:

Table I

\begin{tabular}{|l|l|l|}
\hline \multicolumn{1}{|c|}{ S. No. } & \multicolumn{1}{|c|}{ Nawabs and Kings } & \multicolumn{1}{c}{ Period } \\
\hline 1 & Saadat Khan & September 9, 1722 - March 10, 1739 \\
\hline 2 & Safdar Jang & March 10, 1739 - October 26, 1754 \\
\hline 3 & Shuja-ud-Daulah & October 5, 1754 - January 25, 1775 \\
\hline 4 & Asaf-ud-Daulah & January 27, 1775 - September 21, 1797 \\
\hline 5 & Wazir Ali & September 21, 1797 - January 20, 1798 \\
\hline 6 & Saadat Ali & January 21, 1798 - July 10, 1814 \\
\hline 7 & Ghaziuddin Haidar & July 10, 1814 - October 19, 1827 \\
\hline 8 & Naseer-ud-din Haidar & October 19, 1827 - July 7, 1837 \\
\hline 9 & Muhammad Ali Shah & July $8,1837-$ May 1842 \\
\hline 10 & Amjad Ali Shah & May 17, 1842 - February 13, 1847 \\
\hline 11 & Wajid Ali Shah & February 13, 1847 - February 7, 1856 \\
\hline
\end{tabular}

\section{Districts in Oudh}

Oudh was founded in 1722 by an Iranian adventure entitled Saadat Khan who refused the imperial order transferring him to Malwa, it was among the first regional powers to become independent of Delhi. Even after Wellesley had severely truncate Oudh in 1801, it still held an area of 23,923 square miles, comprising the twelve districts of Lucknow, Sultanpur, Aldermau, Pratapgarh, Panchamrat, Baiswara, Salon, Ahladganj, Gonda-Bahraich, Sarkar-Khairabad, Sandi and Rasulabad. After the establishment of British power these districts were reorganized and renamed as follows: Lucknow, Sitapur, Hardoi, Kheri, Unnao, Rae Bareli, Sultanpur, Bara Banki, Pratapgarh, Faizabad, Gonda and Bahraich.

Table Ii

\begin{tabular}{|l|l|}
\hline \multicolumn{2}{|c|}{ Oudh Region Division } \\
\hline \multicolumn{1}{|c|}{ Lucknow Division } & \multicolumn{1}{c|}{ Fyzabad Division } \\
\hline 1) Lucknow & 1) Fyzabad \\
\hline 2) Unnao & 2) Gonda \\
\hline 3) Rae Bareli & 3) Bahraich \\
\hline 4) Sitapur & 4) Sultanpur \\
\hline 5) Hardoi & 5) Pratabgarh \\
\hline 6) Kheri & 6) Bara Banki \\
\hline
\end{tabular}

\section{Geography}

The Oudh region: a part of the United Provinces, located between $25^{\circ} 34^{\prime}$ and $28^{\circ} 42^{\prime} \mathrm{N}$ and $79^{0} 41^{\prime}$ and $83^{\circ} 8^{\prime} \mathrm{E}$ with an area of 23,966 square miles. Population (1901), 12,833,077. Oudh is bounded on the north by the state of Nepal, and on all other sides by the province of Agra. The Gorakhpur and Benares Divisions lie on the east, the Bareilly and Agra Divisions on the west, and the Allahabad Division on the south. The river Ganges forms the greater part of the south-western boundary. Oudh includes portions of two of the great natural divisions of upper India. The three northern districts of Kheri, Bahraich and Gonda stretch up into the submontane tract lying below the Himalayas; while the remainder of the province is in the central portion of the Gangetic plain. The northern boundary of Bahraich and Gonda runs for 60 miles along the low hills which mark the first rise above the level of plain; but the submuntain tract or Tarai is chiefly distinguished by its greater slope and excessive moisture, due to a heavier rainfall and the drainage from the outer ranges of the Himalayas. In the northern portion of the province there are large areas of forest land geologically the whole of the Oudh is classified as Gangetic alluvium. No rock or stone is found except kankar (nodular lime stone), which is used for metalling roads.

\section{Rivers, Lakes and Ponds}

Rivers have a primary significance in any discussion of ecology. The country slopes from north-west to south-east, and the drainage follows the same line, being divided into two great river systems, those of the Gogra and Ganges, which ultimately unite the Bengal. The province may thus be divided into two tracts separated by the Gogra. On the north-east the districts of Bahraich and Gonda form a triangular area, a portion of which is drained by the Rapti, with a course roughly parallel to that of the Gogra, in to which it falls in Gorakhpur District, while the greater part of the drainage is carried directly into that river. The rest of the province is roughly rectangular in shape, and lies between the Gogra and Ganges. Through the center of this portion flow the Gomti and its southern tributary the Sai, which carry off most of the drainage in to the Ganges, it is only in the northern Districts of Kheri and Sitapur that the Gogra obtains an increase to its volume through the Sarda and its branches. The numerous shallow ponds and jhils, of which the Dahar lake is the most 
important, form a more valuable source for irrigation than the rivers. Ghagra and Rapti are two main rivers of the Gorakhpur district. Sarda, Gumti, Katna, Khanaut, and Deoha are the principal rivers of the Pilibhit district.

\section{Soils}

Soil is another important feature of ecology which deserves to be mentioned. Soil related human relationship to environment. Most part of Oudh, soil was productive, while, it diverse in its contents and quality. The Tarai, on the outskirt of which are situated, as already noted, the more valuable state forests in the Oudh Circle, is formed by the alluvium of the Sarda, the Kauriala, the Rapti and by the deposits of numerous smaller streams debouching from the Himalayan range. For our purpose it may be divided into two main classes. The one is the low-lying unsettled alluvium, which, still in the active process of formation, is constantly subjected to periodical or accidental changes by the diversion of the rivers which interseet it, and which assist in its formation. The second class is he high lying stable ground forming, as a rule, the main watersheds, which have ceased to be subject to changes, but which owe their existence to an action similar to that now observable on the low grounds, as is clearly proved by the numerous lakes, depressions, and traces of old river-beds. In the still forming alluvium periodical and accidental over flows are frequent. The former, the main agent for the formation of the alluvium, are due to the gradual rising of the river beds and their immediate surroundings above the level of country, till the balance is lost, a spill occur, and the course of the river is changed for the time being, again to rise above the general level, and again and again to find a lower bed, thus forming an alluvium by a succession of silt waves, both in direction of the river and vertical to its axis. This action taken place till the country is raised above the influence of natural floods. In some instances the flood and changes in the river courses are due to accidental obstructions, which may cause changes even in an alluvium beyond the influence of ordinary floods; and Mala swamp, which is doubtless a comparatively modern channel of the Sarda cut through an alluvium raised above the ordinary influence, evidently owes its existence to some such accident of considerable magnitude. When the obstruction was removed, the temporary drainage line was no longer required, and became the Mala swamp. Large rivers, like the Sarda and Kauriala, debouching directly from the high hill into the open plains, require extensive play-grounds; and though the sphere of their action has been, as is evident from a study of the country, considerably curtailed in the course of ages, a glance at an accurate map reveals the enormous extent of country which has recently been, or is still, within the direct influence of their action. The subsoil of the stable, as well as the still forming alluvium, is coarse white sand rich in undecomposed mica. On the high stable ground this is covered with a layer of loamy sand, varying in depth from a few feet to 20 feet and more. It is unquestionable that layer of good soil is mainly due to decomposition under the influence of vegetation; for the sand, which underlies these beds of loamy soil, is the same as that carried down by the rivers at present. With the rise of the alluvium the floods become gentler, and more fertile silt is frequently deposited together with the course sand. The degree of decomposition and consequent mellowness and fertility of the soil varies as much as its depth. The sterile sand on the low-lying ground lies frequently exposed, or is only thinly covered by fertile soil, which. Moreover, is usually coarser in its composition, and liable, by the next overflow, to be recovered with fresh river sand. The water flooding the low ground carry large quantities of seeds, as well as silt, and these, as a rule, germinated freely. Frequently the young growth is destroyed again by a subsequent submersion or other accident, and, under these circumstances, the areas are only are only covered with more or less coarse grasses.

\section{Forest distribution in Oudh Region}

The Government Forests of Oudh Circle consisted of the reserves in the Pilibhit and Gorakhpur Districts belonging to the north-west provinces and the reserves in the Kheri, Bahraich and Gonda Districts in Oudh. All these forests were constituted reserves under Section 39 of the Indian Forest Act of 1878 in February $28^{\text {th }} 1879$.

The Himalayas between Nainital Tal and the Rapti generally rise abruptly from the plain into a mountain chain of considerable altitude, and the distinct features of intervening Siwalik and Duns, which characterize the approach to the main mountain ranges further towards the west, are more or less obliterated. The Tarai lies immediately below the high hills. East of the Rapti the outer hill range, as far as it forms the boundary of British Territory, doe not rise above 2,000 feet, and the Siwalik Character of the hills reappears, to be lost again further towards the east, where the plain of Gorakhpur are surrounded by an amphitheatre oh high hills. Where the Tarai Approaches the high range directly and with out intervening Siwaliks, a very extensive and more or less continuous belt of magnificent deciduous forests underlies the hills. These forests are generally known as those of the Nipal Tarai; the bulk of them are situated beyond the British boundry, and the Motipur and the Kheri forests are only portion of the outer and deeply serrated fring of the compact forest area in Nipal, in the same way as the Pilibhit, Puranpur and Bhira forests are the last straggling off-shoots of the most extensive forests of Kumaun Tarai. The Bhinga forests are situated on tarai land formed at the foot of the low Rapti Siwaliks, and the Gorakhpur Forests are the southern extremities of the tarai forests below the 
Deoniagarh. The greater part of these forests is again situated in Nipal. The Tulsipur forests occupy the lower and more gentle slope of the Siwaliks - the debris, so to sat, at the foot of the original hills. The subsoil of this debris consist of disjointed rock, loose shingle, and gravel, into which the water draning down the steeper hill sides sinks rapidly, to reappear only when the general level of the country has been reached. This naturally leaves the surface of the intermediate slope exceedingly dry and fit only to beer a very open forest, mainly composed of Anogeissus lalifolia (Dhau). These forests can be divided into low-lying and high-lying grounds. A forest forms on the low-lying alluvium, of which Dalbergia Sissoo (Shisham) and Acacia Catechu (Khair) are the most characteristic representatives. The stable and high-lying grounds are occupied by forests characterized by Sal (Shorea robusta) and Asseina (Terminalia tomentosa). The Sal tree cannot grow where it is still liable to be flooded, or even where its surface roots suffer from want of drainage; but when this has ceased to be the case, $\mathrm{Sal}$ is a forinidable rival to any other forest tree, owing to its great power of resistance to shade, the facility with which it coppices, its ability to grow closely, and its extraordinary reproductive powers. There is no doubt that the extermination of sissu and khair on the higher grounds, which they must once have occupied, is mainly due to this, though practically this theory can not be able to verify. The division between the Sal forest and miscellaneous forest is not always as abrupt as that between the khair forest and the Sal forest; but broadly speaking, the forests in the Oudh Circle may be divided in to miscellaneous forests, khair forest and Sal forest. The forest in Oudh Circle may be divided into miscellaneous forests, Khair forests and Sal forests. The Government Forest contain, according to the records as Ribbentrop's disposal (1886).

TABLE III

\begin{tabular}{|l|l|}
\hline Type of Forests & Square miles \\
\hline Sal forests & 586 \\
\hline Miscellaneous forests & 89 \\
\hline Low grounds & 245 \\
\hline Phantas & 212 \\
\hline Total & 1,132 \\
\hline
\end{tabular}

This statement, however, gives a by far too favorable picture for the area hare exhibited, as the khair and sissu forests include a considerable extent, probably upwards of 50 per cent., of swamp and ground which are still exposed to annual floods, and which consequently can produce nothing but grass; and even those portions of the low lying land which are capable of growing a khair and sissu forest, and where numerous stamps and remnants of dead trees prove that a forest once existed, are, as a rule, mere grass plains, interspersed with more or less compact plots or belts of forest growth, and here and there studded with single trees, which, for some reason or other, escape the general annual conflagration. The sal forest is the trans-sarda localities, especially those forming the Kasumba and dudua Blocks, also contain large Phantas, or low-lying open patches of ground, on which the water collects during the rains, and which consequently produce nothing but reeds and grass; and those in the cis-Sarda tract include large areas, amounting perhaps to a moiety of the forests, which at present can produce nothing better than an annually dying crop of sal scrub.

TABLE IV

\begin{tabular}{|l|l|l|}
\hline \multicolumn{1}{|c|}{ S. No. } & \multicolumn{1}{|c|}{ Districts } & \multicolumn{1}{c|}{ Forest species } \\
\hline 1 & Bahraich & $\begin{array}{l}\text { Sal, sagaun and shisham. Grass, bamboo, bushes, canes, herbs and } \\
\text { lac. }\end{array}$ \\
\hline 2 & Gonda & $\begin{array}{l}\text { Sal, assina, dhaes, haldu, shisham, khair mahua, semal, jamun, } \\
\text { aonla and ebony }\end{array}$ \\
\hline 3 & Gorakhpur & Jamun, khair, haldu, samel, jhigna, mahua and aonla \\
\hline 4 & Kheri & $\begin{array}{l}\text { Sakhu, sal, asna, haldu, phaldu, asidh, tendu, mahua, domsal, } \\
\text { jamun, bhakmal, semal, shisham, tun, dhak, neem amaltash, imli } \\
\text { and teak. }\end{array}$ \\
\hline 5 & Pilibhit & $\begin{array}{l}\text { Sal, tun, sissu, khair, cane-brakes, jamun, neora, bera, khaja, ilar, } \\
\text { dudhi and Maljhan and ect. }\end{array}$ \\
\hline
\end{tabular}

\section{Conclusion}

The institution of forestry in Oudh region provides an interesting case study of the evolution and changing attitudes towards forests and land use. For the local inhabitants and the villages, this vast expanse of vegetation represented perpetuity, a way of life, an unawareness that this mass could even be exploited or extracted for more than what was required for local use or local consumption. As commercialism and material concerns penetrated into the villages, changes in attitudes became visible. The zamindar of the villages, who had once adamantly stood by their trees, protecting them from human compulsion, bent before the force of commercialism, cutting down trees and even growing trees for timber trade. Forests and forestry significantly 
figured on all government agenda, whether of the East India Company or preceding ones. Forest clearing, expansion of cultivation and the commercial, strategic advantages of forest were known much before the East India Company.

\section{References}

[1] Schlich WM., Schlich's Manual of Forestry, volume 1, Forest Policy in the British Empire (London, Bradbury ,Agnew \& Co. LD., 1922)

[2] Bhargava M, State, Society and Ecology Gorakhpur in Transition 1750-1830 (Delhi, Manohar, 1999)

[3] Qureshi Hamid Afaq, "The Mughals, The English and The Rulers of Awadh, From 1722 A.D. to 1856 A.D. A Laleidoscopic Study (Lucknow , New Royal Book Company, 2003)

[4] Mukherjee Rudrangshu, Awadh in Revolt 1857-1858, A Study Of Popular Resistance (Delhi, permanent black, 2001)

[5] Mukherjee Rudrangshu, Awadh in Revolt 1857-1858, A Study Of Popular Resistance (Delhi, permanent black, 2001)

[6] Bartholomew J.G., United Provinces, Imperial gazetteer of India, Volume 24 (Oxford, Clarendon Press, 1907-1909)

[7] Frowde Henry, The Imperial Gazetteer of the India, Volume XIX, Nayakanhatti to Parbhani (Oxford- At the Clarendon Press, 1908)

[8] Frowde Henry, The Imperial Gazetteer of the India, Volume XIX, Nayakanhatti to Parbhani (Oxford- At the Clarendon Press, 1908)

[9] Frowde Henry, The Imperial Gazetteer of the India, Volume XIX, Nayakanhatti to Parbhani (Oxford- At the Clarendon Press, 1908)

[10] Bhatt S.C., The Encyclopaedic District Gazetters of India, Vol. 6(Uttar Pradesh ) (New Delhi, Gyan Publication, 2009)

[11] Frowde Henry, The Imperial Gazetteer of the India, Volume XX,Pardi to Pusad (Oxford- At the Clarendon Press, 1908)

[12] Ribbentrop B., Note on an Inspection of the Forest in Oudh in March and April 1886, (Simla, Government Central Branch Press, 1886)

[13] Ribbentrop B., Note on an Inspection of the Forest in Oudh in March and April 1886 (Simla, Government Central Branch Press, 1886)

[14] Ribbentrop B., Note on an Inspection of the Forest in Oudh in March and April 1886, (Simla, Government Central Branch Press, 1886)

[15] Ribbentrop B., Note on an Inspection of the Forest in Oudh in March and April 1886, (Simla, Government Central Branch Press, 1886)

[16] Bhatt S.C., The Encyclopaedic District Gazetters of India, Vol. 6(Uttar Pradesh) (New Delhi, Gyan Publication,2009)

[17] Bhatt S.C., The Encyclopaedic District Gazetters of India, Vol. 6(Uttar Pradesh ) (New Delhi, Gyan Publication,2009)

[18] Bhatt S.C., The Encyclopaedic District Gazetters of India, Vol. 6(Uttar Pradesh ) (New Delhi, Gyan Publication, 2009)

[19] Bhatt S.C., The Encyclopaedic District Gazetters of India, Vol. 6(Uttar Pradesh ) (New Delhi, Gyan Publication,2009)

[20] These species name has been derived from Working Plan of the Pilibhit Forest Division, 1923-24 to 1932-33 